\title{
Keeping Pace with the Changing Face of Canadian Nursing - Suivre le rythme du profil changeant des infirmières au Canada
}

Florence Myrick

amyrick@ualberta.ca

Jacinthe I. Pepin

Université de Montréal, jacinthe.pepin@umontreal.ca

Follow this and additional works at: https://qane-afi.casn.ca/journal

\section{Recommended Citation}

Myrick, Florence and Pepin, Jacinthe I. (2018) "Keeping Pace with the Changing Face of Canadian Nursing - Suivre le rythme du profil changeant des infirmières au Canada," Quality Advancement in Nursing Education - Avancées en formation infirmière: Vol. 4: Iss. 2, Article 8.

DOI: https://doi.org/10.17483/2368-6669.1191

This Interview is brought to you for free and open access by Quality Advancement in Nursing Education - Avancées en formation infirmière. It has been accepted for inclusion in Quality Advancement in Nursing Education - Avancées en formation infirmière by an authorized editor of Quality Advancement in Nursing Education - Avancées en formation infirmière. 
Myrick and Pepin: Keeping Pace with the Changing Face of Canadian Nursing - Suivre

\section{Keeping Pace with the Changing Face of Canadian Nursing}

Interviewee: Dr. Linda McGillis Hall, RN, PhD

Interviewer: Dr. Florence Myrick, Co-Editor-inChief

Dr. Myrick: Good morning Dr. Hall. On behalf of my Co-Editor-in-Chief, Dr. Jacinthe Pepin, and myself, I want to thank you for agreeing to this interview and to congratulate you on your Pat Griffin Scholar Award.

Dr. Hall: Thank you so much. It was a great honour to receive this prestigious award.

Dr. Myrick: The focus of our interview today is keeping pace with the changing face of Canadian nursing. To that end, I would like to engage you in discussion on this particular topic considering your extensive background and the research you have conducted concerning international nursing within Canada. I would like to begin by asking if you could share with our readers your perspective on the current status of internationally educated nurses (IENs) practicing in Canada.

Dr. Hall: As a nursing education and workforce researcher coming from the perspective of workforce planning and monitoring, it is interesting when you look at the numbers, or the supply, of internationally educated nurses in Canada, as well as their practice experiences. According to ten years of trend data reported by the Canadian Institute of Health Information (CIHI) in 2018, IENs have consistently made up approximately $10 \%$ of the regulated nursing workforce, with a small increase of $1 \%$ notable in the past two years (CIHI, 2018b). When you think of Canada's global position on immigration from a political perspective, and our corresponding immigration programs, these IEN numbers are interesting. A combination of factors has likely contributed to this. While we've seen growth in the supply of regulated nurses in Canada in the past ten years (16.4\% overall, $1.7 \%$ annually), the cumulative growth of registered nurses (RNs) and nurse practitioners (NPs) has been substantially slower $(7.8 \%$ overall, $0.8 \%$ annually) than that of

\section{Suivre le rythme du profil changeant des infirmières au Canada}

\author{
Invitée : Dre. Linda McGillis Hall, RN, PhD
}

Intervieweuse : $D^{\text {re }}$ Florence Myrick, Corédactrice en chef

$D^{\text {re }}$ Myrick : Bonjour $\mathrm{D}^{\text {re }}$ Hall. Au nom de la corédactrice en chef, la $\mathrm{D}^{\text {re }}$ Jacinthe Pepin, et moi-même, je vous remercie d'avoir accepté cette entrevue et je tiens à vous féliciter pour votre nomination au poste de recherche en formation infirmière Pat Griffin.

$D^{\text {re }}$ Hall : Merci beaucoup. Ce fut un grand honneur de recevoir ce prix prestigieux.

$D^{\text {re }}$ Myrick : Notre entretien d'aujourd'hui porte sur la façon de suivre le rythme du profil changeant des infirmières au Canada. Je tenais particulièrement à aborder ce sujet avec vous compte tenu de votre importante expertise et de la recherche que vous avez menée auprès des infirmières formées à l'étranger qui pratiquent au pays. J'aimerais premièrement connaître votre point de vue sur le statut actuel des infirmières formées à l'étranger (IFE) qui pratiquent au Canada.

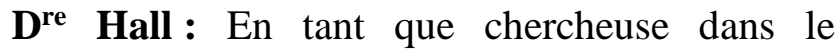
domaine de la formation et de la main-d'œuvre en sciences infirmières, il est intéressant d'examiner, en termes de nombres, la disponibilité d'infirmières formées à l'étranger au Canada, ainsi que leurs expériences de pratique. Selon les tendances sur 10 ans observées dans les données de l'Institut canadien d'information sur la santé (ICIS) en 2018, les IFE ont toujours représenté environ $10 \%$ de la main-d'œuvre infirmière, avec une légère augmentation de $1 \%$ au cours des deux dernières années (ICIS, 2018b). Lorsque nous pensons aux politiques du Canada sur l'immigration et aux programmes d'immigration qui en résultent, ces chiffres sur les IFE sont intéressants et sont sans doute influencés par une combinaison de facteurs. Bien que nous ayons connu une augmentation des effectifs des infirmières au Canada au cours des 10 dernières années $(16,4 \%$ 
practical nurses (PNs), which has soared to $46.5 \%$ (4-5\% annual growth) over this same time period (CIHI, 2018a). These changes highlight the importance of examining all categories of the workforce within nursing, to monitor it over time, and to be aware of where changes are taking place and what implications they may have on nursing education, practice, and policy. There is some evidence to suggest that IENs entering the country move into non-RN roles while they are waiting for or working towards $\mathrm{RN}$ licensure, but that is unlikely to be the sole explanation for the shifts we are seeing. Corresponding with these demographic changes in the nursing workforce, this past spring we saw the Canadian Nurses Association (CNA) expand their membership beyond that of RNs and NPs to include PNs and registered psychiatric nurses (RPNs), as they serve as the professional voice for all nurses in the country. Also, when you drill down and explore the IEN supply data further, you see that the highest volumes annually come from five countries, led by the Philippines.

Dr. Myrick: So nurses from the Philippines constitute the largest group of nurses migrating to Canada then, compared with other countries?

Dr. Hall: Yes, the largest percentages of nurses migrating to Canada over time have come from the Philippines, and currently they comprise close to a quarter of our IEN population in Canada (7,977 of 36,730 IENs (CIHI, 2018b)). This is followed by India with 2,664 , the UK $(2,080)$, the US $(1,559)$, and France $(1,159)$ (CIHI, 2018b). We've seen fluctuations in these trends in particular years, for example with migrants from India increasing recently, while those from the UK have decreased, and we also see that the US numbers are starting to increase slightly.

Dr. Myrick: That is indeed interesting, isn't it?

Dr. Hall: Yes, perhaps as a reflection of the political climate in the US or potentially with the shift in our licensure exam for nursing. When the NCLEX was adopted in Canada, there was concern that it may contribute to Canadian nurse migration to the US or a more fluid boundary across the border for the nursing workforce. Our earlier research demonstrated that we have a au total, 1,7\% annuellement), la croissance cumulative du nombre d'infirmières (I) et d'infirmières praticiennes (IP) a été beaucoup moins importante $(7,8 \%$ au total, $0,8 \%$ annuellement) que celle des infirmières auxiliaires (IA), qui a explosée de 46,5 \% (4-5\% de croissance annuelle) pendant la même période (ICIS, 2018a). Ces changements soulignent l'importance d'examiner toutes les catégories de personnel en soins infirmiers, d'en faire le suivi au fil du temps, et de considérer où ces changements ont lieu de même que leurs effets sur la formation, la pratique et les politiques quant aux soins infirmiers. Bien que certaines données laissent croire que les IFE qui arrivent au Canada vont vers des rôles autres que celui d'infirmières en attendant de recevoir leur permis d'exercice ou pendant leurs études, il est peu probable que ceci soit le seul facteur responsable des changements auxquels nous assistons. En plus des changements démographiques dans la main-d'œuvre en soins infirmiers, au printemps dernier, l'Association des infirmières et infirmiers du Canada (AIIC) a élargi son bassin de membres, jusqu'alors composé d'I et d'IP, pour inclure les IA et les infirmières psychiatriques et ainsi représenter tous les groupes d'infirmières du Canada. De plus, lorsque nous approfondissons davantage les données sur les effectifs des IFE, nous observons que la majorité d'entre elles proviennent de cinq pays, le plus important étant les Philippines.

$D^{\text {re }}$ Myrick : Les infirmières des Philippines (comparativement à celles d'autres pays) représentent donc le groupe le plus important d'infirmières qui immigrent au Canada?

$D^{\text {re }}$ Hall : Oui, au fil du temps, le plus grand pourcentage d'infirmières qui immigrent au Canada vient des Philippines, et elles représentent actuellement près d'un quart des IFE au Canada (7 977 sur 36730 IFE [ICIS, 2018b]). Elles viennent également de l'Inde (2 664), de la Grande-Bretagne (2 080), des États-Unis (1 559) et de la France (1 159) (ICIS, 2018b). Ces tendances fluctuent tout de même certaines années, un exemple de ceci étant l'augmentation récente des immigrantes en 
decades-long history of successful nurse migration and integration to the US.

Dr. Myrick: I think it is important information for our readers to become aware of the change that has occurred over time from that perspective.

Dr. Hall: Yes, although in other research we have conducted with IENs employed in Canada, they talked a lot about their integration experiences and some of the challenges that they encountered. They migrated primarily for personal reasons such as to bring their family to a safer or a "better" country than that which they had left. Factors such as salary and working conditions were important considerations, but in our study, IENs identified that they had not been recruited to come to Canada. While a few Canadian provinces have employed international recruitment initiatives at some point in time, in comparison, it is well known that recruiters come to Canada, hold job fairs, and actively seek Canadian nurses to work internationally. Canadian nurses are held in high esteem; they have a very high reputation for being able to move and integrate well into other health care systems, especially the US, which has been well documented in the literature.

Dr. Myrick: In keeping with that perspective and your research, what would you say are the major challenges for IENs? In particular, with what particular issues are they confronted as they embark upon their career here?

Dr. Hall: Their greatest challenges were taking the licensure exam, and over 1,400 of the respondents in that study (about $72 \%$ of the sample), commented on this fact (McGillis Hall, Jones, Lalonde, Strudwick, \& McDonald, 2015). It was by far the largest issue, and I think one which has come to light even further with the implementation of the NCLEX exam here in Canada. IENs in Canada writing the NCLEX are not doing well on the exam. Most disturbingly, they appear to be doing poorer over time.

Dr. Myrick: Can you give an average of their percentage of success? provenance de l'Inde et la diminution de celles provenant de la Grande-Bretagne. Le nombre d'infirmières en provenance des États-Unis a également commencé à augmenter un peu.

D $^{\text {re }}$ Myrick : C'est très intéressant, n'est-ce pas?

$D^{\text {re }}$ Hall : Effectivement. Il s'agit peut-être d'un reflet du climat politique aux Etats-Unis, ou encore du changement de notre examen pour l'obtention du permis d'exercice infirmier. Au moment de l'introduction de l'examen NCLEX au Canada, certaines craignaient que cela facilite l'émigration des infirmières canadiennes vers les États-Unis ou rende la frontière entre les pays plus fluide pour les effectifs infirmiers. Nos études antérieures démontraient que les infirmières du Canada émigrent et s'intègrent au sud de la frontière depuis plusieurs dizaines d'années.

$D^{\text {re }}$ Myrick : Je crois qu'il est important que nos lectrices soient conscientes du changement qui s'est opéré en ce sens au fil du temps.

$D^{\text {re }}$ Hall : Oui, il est important de souligner que d'autres recherches effectuées auprès d'IFE qui pratiquent au Canada ont révélé que celles-ci parlaient beaucoup de leurs expériences et de défis rencontrés au cours de leur intégration. Elles mentionnaient notamment avoir émigré principalement pour des raisons personnelles, comme amener leur famille dans un pays plus sécuritaire ou «meilleur » que celui d'où elles provenaient. Les facteurs comme le salaire et les conditions de travail étaient importants, mais les IFE ayant participé à notre étude ont affirmé qu'elles n'avaient pas été recrutées pour venir au Canada. Certaines provinces canadiennes ont déjà entrepris des initiatives de recrutement international par le passé, mais il est également reconnu que les recruteurs viennent au Canada en quête d'infirmières canadiennes souhaitant travailler à l'étranger. Les infirmières canadiennes sont tenues en haute estime, et ce qui est bien documenté dans les écrits, c'est qu'elles sont appréciées pour leur capacité à se déplacer et à bien s'intégrer dans d'autres systèmes de santé, particulièrement aux ÉtatsUnis. 
Dr. Hall: Yes; overall the first-attempt IEN writers scored poorly in the first year Canada offered the NCLEX, in $2015(49.7 \%)$, then improved substantially in 2016 (69.4\%). However, the pass rate dropped again to $59.1 \%$ in 2017 (Canadian Council of Registered Nurse Regulators, 2017). Similarly, the IEN year-end pass rate after all attempts at the exam show the same pattern: $73.3 \%$ successfully passing in 2015 , $81.7 \%$ in 2016, and down again to $68.5 \%$ in 2017 . While it is possible that these 2017 pass rates may change modestly when the final numbers are tabulated in the next reports, we don't know why exactly they fell, and certainly their overall pass rates over the years are quite low.

Dr. Myrick: How does it compare with how Canadian-educated nurses are doing on the NCLEX?

Dr. Hall: The Canadian-educated nurses writing the NCLEX started off doing poorly as well: their first-attempt pass rate was $69.7 \%$ in 2015 and $79.9 \%$ in 2016 , and then it increased to $82.1 \%$ in 2017. Their year-end pass rate was different: $95.0 \%$ in $2015 ; 96.3 \%$ in 2016 , and down to $90.2 \%$ in 2017. So, as it stands, Canadian-educated writers are achieving an $82 \%$ pass rate on their first attempt at writing the NCLEX as of 2017, but IENs are only achieving a $59.1 \%$ pass rate on their first attempt, and that is a concern.

Dr. Myrick: Would you say it may have something to do with the international nurse not being entirely familiar with the kind of exam that the NCLEX is?

Dr. Hall: We can see how IENs from a few different countries did on the exam. For example, the pass rates for IEN writers educated in the five countries that represent the highest volume of exam writers on the NCLEX here in Canada are available. The countries that our IEN NCLEX writers represent are, for the most part, similar to the those reported in the ten-year data trends found in the 2018 CIHI report. These countries are India, the Philippines, the United Kingdom, Australia, and Jamaica (CIHI, 2018b). Of interest, the writers who have done the best on the NCLEX in all three years are from the Philippines $(2015=66.9 \%$,
D ${ }^{\text {re }}$ Myrick : Dans cet ordre d'idée à partir de votre recherche, selon vous, quels sont les principaux défis pour les IFE? Et plus particulièrement, à quels genres de problèmes font-elles face en début de carrière au Canada?

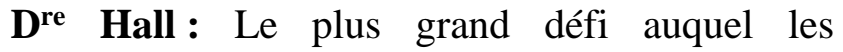
participantes de l'étude faisaient face était de faire l'examen du permis d'exercice, un défi mentionné par plus de 1400 participantes (environ $72 \%$ de l'échantillon) (McGillis Hall, Jones, Lalonde, Strudwick et McDonald, 2015). Cela était de loin le défi mentionné le plus fréquemment, et je crois qu'il est encore plus évident depuis l'adoption du NCLEX au Canada. Les IFE qui passent le NCLEX ici ne réussissent pas bien à l'examen. Le plus troublant est qu'elles semblent performer de moins en moins bien avec le temps.

$D^{\text {re }}$ Myrick : Avez-vous des données sur le taux moyen de réussite?

$D^{\text {re }}$ Hall : Oui. En 2015, la première année de l'examen NCLEX au Canada, les IFE qui le passaient pour la première fois n'ont pas bien réussi $(49,7 \%)$, mais ceci fut suivi d'une importante augmentation en 2016 (69,4\%). Cependant, le taux de réussite a diminué à nouveau en 2017 (59,1 \%) (Canadian Council of Registered Nurse Regulators, 2017). Le taux de réussite final après toutes les tentatives permises suit la même tendance : un taux de réussite de $73,3 \%$ en 2015 , de $81,7 \%$ en 2016 , et de $68,5 \%$ (une baisse) en 2017. Bien que le taux de réussite de 2017 puisse changer légèrement lorsque tous les résultats seront compilés dans les prochains rapports, nous ne savons pas pourquoi il a diminué. En conclusion, le taux de réussite en général au fil des ans est plutôt bas.

$D^{\text {re }}$ Myrick : Comment ces résultats au NCLEX se comparent-ils à ceux des infirmières formées au Canada?

$D^{\text {re }}$ Hall : Les infirmières formées au Canada qui passent le NCLEX n'ont pas obtenu de bons résultats non plus au début : leur taux de réussite au premier essai, en 2015 , était de $69,7 \%$, puis de $79,9 \%$ en 2016 , et de $82,1 \%$ en 2017 . Leur 
$2016=73.4 \%$, and $2017=72.7 \%$ ). And their pass rates are higher than those writers from the other countries comprising this group. That no doubt has a lot to do with what some authors describe as the export-oriented education system in the Philippines, which is well known for educating nurses for out migration. It is also important to note that, the IEN group in Canada which represents the largest volume of writers annually comes from India, and they consistently have been scoring the lowest on the NCLEX $(2015=35.7 \%$, $2016=56.1 \%$, and $2017=47.5 \%$ ). In this context, I think it may be important to consider language issues with the exam. We have learned, for example, that our Francophone writers experience issues with the NCLEX, some of which may be considered language-related or culturally sensitive. It is not merely a simple translation from French to English.

Dr. Myrick: That leads me to my next question: how can the Canadian Association of Schools of Nursing, and indeed nurse educators generally, continue to adequately support IENs as they prepare for and engage in nursing practice in Canada?

Dr. Hall: We really have to continue to monitor these trends in the context of what is occurring politically and in practice. Remember that we also saw a very small drop $(0.8 \%)$ in the number of graduates from our undergraduate programs in the last CASN report released in December 2017: from 12,579 in 2015 to 12,484 in 2016 (CASN, 2017). It is important for all of us as educators to be aware of shifts that are happening in the workforce and consider them as a whole. The consistently low pass rates for IENs on the NCLEX exam is a concern. What needs to be done to improve this situation? Do we know what happens to the IENs who don't pass? Can we learn from the programs that are in place that are focused on supporting IEN integration to practice? We are all very aware of the concerns that Francophone writers have had with the NCLEX exam, but much less attention has been paid to the challenges faced by IENs. Perhaps it is a reflection that currently there are no concerns of a nursing workforce shortage in Canada being voiced at the national level by policy or practice leaders. taux final de réussite était différent : $95 \%$ en 2015, 96,3\% en 2016 , et $90,2 \%$ (une baisse) en 2017. En ce moment, les infirmières formées au Canada obtiennent, depuis 2017, un taux de réussite de $82 \%$ à leur premier essai au NCLEX, alors que les IFE n'obtiennent qu'un taux de $59,1 \%$, une réalité qui s'avère préoccupante.

$D^{\text {re }}$ Myrick : Croyez-vous que le fait que les infirmières formées à l'étranger ne soient pas familières avec le genre d'examen qu'est le NCLEX pourrait être en cause?

$\mathrm{D}^{\text {re }}$ Hall : Nous avons des données sur l'examen pour des infirmières provenant de différents pays. Par exemple, il est possible de voir le taux de réussite des IFE formées dans les cinq pays qui représentent la majorité de celles qui font l'examen. Ces pays sont, pour la plupart, les mêmes que ceux retrouvés dans les données sur 10 ans du rapport 2018 du ICIS, soit l'Inde, les Philippines, la Grande-Bretagne, l'Australie et la Jamaïque (ICIS, 2018b). Il est intéressant de voir que les infirmières ayant obtenu les meilleurs résultats pendant les trois années du NCLEX sont celles venant des Philippines $(2015=$ $66,9 \%, 2016=73,4 \%, 2017=72,7 \%)$. Leur taux global de réussite est plus élevé que celui des infirmières des autres pays dans ce même groupe. Cela s'explique sans aucun doute par ce que certains auteurs décrivent comme le système d'éducation orienté vers l'exportation dans les Philippines, et qui est connu pour former les infirmières afin qu'elles puissent émigrer. Il est aussi important de noter que le groupe d'IFE au Canada qui représente le plus grand nombre d'infirmières passant l'examen annuellement provient de l'Inde, et que celles-ci obtiennent toujours de faibles résultats au NCLEX (2015 = $35,7 \%, 2016=56,1 \%, 2017=47,5 \%)$. Dans ce contexte, je crois qu'il est important de considérer la barrière de la langue lors de l'examen. Par exemple, nous avons appris que les étudiantes francophones formées au Canada connaissent des difficultés, certaines pouvant être liées à la langue ou à la culture. Il ne s'agit pas seulement d'une traduction de l'anglais au français. 
Dr. Myrick: In terms of supporting the internationally educated nurse, is there anything specific in place that would offer them a form of mentorship in any way? We talk a lot about mentorship in nursing, even for our own young nurses, and I was wondering if there is anything that has been created along those lines?

Dr. Hall: There is a consortium across I believe it is four universities in Ontario that I'm aware of, that received a grant from the Ontario Ministry of Education to develop courses that address specific competency-based educational needs of IENs (Council of Ontario Universities, 2017). It isn't a formal mentorship program, but it is a model that is addressing IEN needs for bridging to practice and for effectively preparing them for success on the NCLEX. We could learn from them about what has been most effective in order to assist other schools who wish to implement similar initiatives. In addition, CASN has information in a 2012 report on their website that highlights some guiding principles for schools of nursing regarding IEN bridging programs. So there is some evidence of strategies that can be used to support and mentor IENs.

Dr. Myrick: What ethical responsibility does Canada have in recruiting IENs, especially from developing countries? For example, the International Council of Nurses (ICN) position statement on ethical recruitment emphasizes the adverse consequences that international migration may have on the quality of health care in countries already reporting a shortage of nurses. As you noted earlier, in Canada we do not tend to do as much active recruiting, but $I$ think it is an issue about which our readers might like to be informed.

Dr. Hall: Again, I think it is a matter of monitoring and being aware of our IEN population, from what countries they are coming and where there are changes in migration patterns. While Canada does not do much active recruitment of nurses from other countries, our immigration process supports IEN migration, thus we should be aware of position statements such as those from ICN on ethical IEN nurse recruitment. Our research suggests that Canada is a preferred
$D^{\text {re }}$ Myrick : Cette réponse mène à ma prochaine question: comment l'Association canadienne des écoles de sciences infirmières (ACÉSI) et les professeures en sciences infirmières peuvent-elles continuer à soutenir de manière adéquate les IFE lorsqu'elles se préparent à la pratique infirmière au Canada?

$D^{\text {re }}$ Hall : Nous devons continuer de suivre ces tendances dans le contexte politique et dans la pratique. Il faut se rappeler que nous avons connu une légère baisse $(0,8 \%)$ du nombre d'infirmières diplômées de nos programmes de premier cycle dans le dernier rapport de l'ACESI publié en décembre 2017, ce chiffre étant passé de 12579 en 2015 à 12484 en 2016 (ACESI, 2017). Il est important pour nous, en tant que professeures, d'être conscientes des changements qui se produisent dans la main-d'œuvre et de les considérer dans leur ensemble. Le taux de réussite systématiquement bas des IFE lors du NCLEX est en fait un problème. Que devrionsnous faire pour améliorer la situation? Savonsnous ce que font les IFE qui ne réussissent pas? Pouvons-nous apprendre des programmes existants qui se centrent sur l'intégration des IFE dans la pratique? Nous sommes toutes très conscientes des inquiétudes des étudiantes francophones concernant le NCLEX, mais les défis que rencontrent les IFE n'ont pas attirés autant l'attention. Peut-être est-ce simplement dû au fait que pour le moment, les responsables des politiques et de la pratique à l'échelle nationale n'expriment aucune préoccupation quant au manque de main-d'œuvre infirmière au Canada.

$D^{\text {re }}$ Myrick : Existe-t-il une forme de mentorat qui pourrait soutenir les infirmières formées à l'étranger? Nous parlons beaucoup de mentorat en sciences infirmières, même pour notre propre relève infirmière, et je me demandais si quelque chose a été mis en place en ce sens.

$D^{\text {re }}$ Hall : Je sais qu'il y a un consortium regroupant, il me semble, quatre universités en Ontario et qui a reçu une subvention du ministère de l'Éducation de cette province afin d'élaborer des cours qui répondent spécifiquement à des besoins de formation en termes de développement de compétences des IFE 
destination for IENs, so unless something markedly changes, that perception is likely to continue. And we are learning globally that nurses are often the main breadwinner for the family; they are often the family member who has sustained employment and are earning the regular salary in the family. As such, they are making the choices about the safety of the family, like moving them to a country where they have the ability to ensure their children grow up in a safer environment, have opportunities for education and a career, and thus be positioned to do well in life in the future. And as long as Canada is considered a country of choice for immigration, I think we can expect to see shifts in immigration patterns from nurses in developing countries in the future.

Dr. Myrick: An interesting topic for research then! Do you think the population of nursing across the country is aware of that issue?

Dr. Hall: The nursing reports from CIHI are produced yearly and there are media releases each time, but these may not always generate a high level of interest. The intensity of media interest may relate to what is going on in the health care environment in Canada at that time, whether we are experiencing a nursing shortage, or whether the reports are identifying any newsworthy difference or changes. The nursing population across Canada is likely aware at a local level of the subtle shifts to the nursing workforce, but nurses may not be as aware of the scope of these changes across the country. We should be thinking about what the changing needs are of our population and, correspondingly, what the appropriate education and skill level should be for that population. This will no doubt have an impact on our educational programs. In terms of IENs, we need to bear in mind that they bring a wealth of knowledge and experience with them when they come to Canada, which can be of great benefit to care provision in our work environments. This is particularly important in a multicultural country like Canada. So I think it is important that we look for ways to ensure IENs are successfully integrated into our health care work environments and that they are provided with the opportunities to work to the full scope of practice for which they are prepared. And perhaps CASN can continue to play a role in
(Council of Ontario Universities, 2017). Il ne s'agit pas d'un programme de mentorat formel, mais c'est tout de même un modèle qui répond aux besoins des IFE en préparation à l'examen NCLEX et à la transition à la pratique. Les universités concernées pourraient partager ce qui a été le plus efficace, et ainsi aider d'autres établissements d'enseignement qui désirent mettre en place des initiatives semblables. De plus, sur le site Web de l'ACESI, se trouve un rapport de 2012 qui fait mention de principes directeurs concernant les programmes de transition pour les IFE dans les écoles de sciences infirmières. Il y a donc des stratégies qui se sont quand même avérées efficaces pour soutenir et guider les IFE.

$D^{\text {re }}$ Myrick : Quelle est la responsabilité éthique du Canada en ce qui concerne le recrutement des IFE, plus particulièrement dans les pays en développement? Par exemple, l'énoncé de position du Conseil international des infirmières (CII) sur le recrutement éthique souligne les conséquences néfastes de la migration internationale sur la qualité des soins de santé dans les pays qui connaissent déjà un manque d'infirmières. Comme vous l'avez mentionné plus tôt, nous ne faisons pas tellement de recrutement actif au Canada, mais je crois que ceci est tout de même un sujet à propos duquel nos lectrices aimeraient en savoir davantage.

$D^{\text {re }}$ Hall : Une fois de plus, je crois qu'il s'agit de suivre et d'être conscientes de nos groupes d'IFE, des pays dont elles proviennent et des changements dans les tendances de migration. Bien que le Canada fasse peu de recrutement actif d'infirmières d'autres pays, notre processus d'immigration soutient la migration des IFE, nous devons donc être conscientes des énoncés de position comme celui du CII concernant le recrutement éthique des IFE. Notre recherche suggère que le Canada est une destination de choix pour les IFE, alors à moins d'un changement notable, cette perception va se perpétuer. Nous apprenons qu'à l'échelle planétaire, les infirmières sont souvent le principal soutien de leur famille, étant donné leur emploi stable et leur salaire versé régulièrement. Elles prennent d'ailleurs souvent les décisions 
raising the awareness.

Dr. Myrick: Could you expand on CIHI for our readers?

Dr. Hall: The Canadian Institute of Health Information (CIHI) is an independent not-for profit organization that has developed and maintained various health care related databases over the years, from which they produce a number of different reports. One of those is an annual report on characteristics of the supply of nurses in the health care workforce. Those reports gather data from a variety of sources (e.g., CNA, CASN, CNSA), to provide a snapshot on the state of the profession each year: giving jurisdictional and national breakdowns on indicators considered of interest to understand the state of the nursing supply in the country. We now have ten years of data, going back to 2008, that can be used to monitor trends and patterns for each of the regulated nursing groups. Some of the indicators include the number of graduates from nursing programs, the numbers of Canadian nurses who hold additional specialty certification from CNA, trends on outmigration of new graduates, and quite a number of supply variables related to factors such as age, employment status, and location of employment (to mention a few). This is a rich information and data source that we are very fortunate to have here in Canada.

These data are also important for us because at CASN we educate nurses and evaluate/accredit the nursing programs for nurses; it is important to be aware of information about what is happening to the nursing workforce. Often the trends and patterns we see in the annual CIHI reports can help explain what we are experiencing in our educational institutions in terms of applicants and programs of interest.

Dr. Myrick: Yes, that is an excellent point. Would you agree with the sentiment that unless the underlying causes of nurse shortages in different countries are addressed, shortages will continue? And what are the actions that need to be taken by nurse educators in that regard? I realize you say that we don't seem to be positing nationally that we have the shortages they seem to have in other concernant la sécurité de leur famille, comme de déménager dans un pays où elles peuvent s'assurer que leurs enfants grandissent dans un environnement sécuritaire et ont la possibilité d'étudier et d'avoir une carrière afin de leur assurer un bel avenir. Tant que le Canada sera considéré comme un pays de choix pour l'immigration, je crois que dans l'avenir nous pouvons nous attendre à des changements dans les tendances d'immigration des infirmières en provenance de pays en développement.

$D^{\text {re }}$ Myrick : Il s'agit donc d'un sujet de recherche intéressant! Pensez-vous que les infirmières au pays sont conscientes de cet enjeu?

$D^{\text {re }}$ Hall : Les rapports sur les sciences infirmières de l'Institut canadien d'information sur la santé (ICIS), accompagnés de communiqués de presse, sont publiés annuellement, mais il est possible qu'ils ne suscitent pas un grand intérêt. Le niveau d'intérêt de la part des médias peut être lié à l'actualité dans les soins de santé au Canada pendant cette période; si nous vivons une pénurie d'infirmières, ou si les rapports identifient d'importants changements dignes d'une couverture médiatique. Les infirmières au Canada sont probablement conscientes des changements de main d'œuvre perceptibles au niveau local, mais sans doute pas au courant de l'étendue de ces changements partout au pays. Nous devrions penser aux besoins changeants du groupe des infirmières et ainsi à la formation pertinente et au niveau de compétences requis. Il ne fait aucun doute que cela aura un impact sur nos programmes de formation. Concernant les IFE, nous devons nous rappeler qu'elles ont des connaissances et de l'expérience lorsqu'elles arrivent au Canada, ce qui peut être bénéfique pour les prestations de soins dans nos environnements de travail. Cela est particulièrement important dans un pays multiculturel comme le Canada. Je crois qu'il est crucial de trouver des façons de bien intégrer les IFE dans le système de santé et de leur permettre de pratiquer à leur plein potentiel. Peut-être que l'ACESI peut continuer à jouer un rôle dans ce travail de sensibilisation. 
countries, but as a global perspective.

Dr. Hall: That is a tough question and there is no easy answer. My personal belief is that some of the main causes of a nursing shortage, other than a lack of adequate health human resource planning, are related to work environments, working conditions, and the migration of nurses. Nurses will leave (or migrate), whether it is within provinces/territories or to a different country, to be able to grow and develop in a better work environment. In research I did during a previous nursing shortage here in Canada, examining Canadian nurse migration to the US, I was amazed at the amount of attention nurses paid to work environments and working conditions in their jobseeking behaviours. It was not (as many people think) salary, benefits, or a sunny climate that were their key motivators. They studied organizational websites, looking for evidence of how nursing was positioned on the website, what opportunities were described for continuing education, and what their position and support was for ongoing graduate education. They were very quick to articulate to me that if you do not see much about nursing on the website, it made them reconsider their interest in that organization, as they interpreted this as meaning that nursing is not very well developed professionally in those organizations.

We have to be aware of what our graduates are seeking. We need to be aware of that for the newer generations emerging. I heard a news bulletin this week that was talking in a general sense, about how this generation wants to receive information. They do not want a lengthy report or article; they want a fact sheet. They want their information fast, precise, and complete; they want to be able to make a decision and move on. If they want more in-depth information on a topic, then they will go and find it. Therefore, our generational understanding of what nurses seek is changing as well. In terms of nursing shortages, we need to be aware of when there is a shortage. Thus, depending on where you are in the country now and to whom you are speaking, they may feel there is a shortage. It is similar in the US, some researchers are saying there is a shortage, some are not. So it really is one of those points where you say "it depends". But the challenge is to not reach
$D^{\text {re }}$ Myrick : Pouvez-vous nous parler un peu plus de 1'ICIS?

$D^{\text {re }}$ Hall : L'Institut canadien d'information sur la santé (ICIS) est un organisme indépendant à but non lucratif qui a développé et mis à jour plusieurs bases de données sur les soins de santé au fil des années, données qui servent à la préparation de divers rapports. L'un de ceux-ci est le rapport annuel sur les caractéristiques des infirmières dans la main-d'œuvre en soins de santé. Ces rapports rassemblent des données provenant de plusieurs sources (p. ex, AIIC, ACESI, AIEC) afin d'offrir un aperçu de l'état de la profession chaque année; ils fournissent des analyses spécifiques par province ou pour le Canada concernant divers indicateurs pour mieux comprendre l'état de l'effectif infirmier au pays. Nous avons maintenant des données sur 10 ans, données qui peuvent être utilisées pour suivre les tendances et les récurrences applicables à chacun des groupes d'infirmières réglementées. Ces indicateurs comprennent le nombre de diplômées des programmes de sciences infirmières, le nombre d'infirmières canadiennes qui détiennent des certifications supplémentaires de l'AIIC, les tendances sur l'émigration des nouvelles diplômées et plusieurs variables sur les effectifs dont l'âge, la situation d'emploi et l'emplacement géographique de l'emploi. Nous sommes choyées d'avoir une source d'information et de données aussi riche que celle-ci au Canada.

Ces données sont également importantes pour nous à l'ACESI, car nous formons des infirmières et nous évaluons et accordons les accréditations aux programmes de sciences infirmières. Il est important d'être informées des changements sur le plan de la main-d'œuvre infirmière. Les tendances et les récurrences que nous observons dans les rapports de l'ICIS peuvent souvent expliquer ce que nous vivons dans les établissements d'enseignement quant aux candidates à l'admission et quant à l'intérêt pour les programmes.

$D^{\text {re }}$ Myrick : Oui, il s'agit d'un bon point. Êtesvous d'accord avec l'idée que la pénurie 
a point where we are actually in a shortage. Indeed, why do we have to even reach a shortage? At a health policy level, are we monitoring and ensuring that we have the workforce supply that we need for the type of person for whom we are caring, whether it is in the community, in the home, or in a health care setting? Without an Office of Nursing Policy and a Principal Nurse for the country in Canada anymore, this is a hard question to answer. When we have this loss of positioning of a federal nursing voice in the country and, in some cases, see variations at the provincial and territorial level in these roles, there is a real need for CASN to continue to work with other federal nursing stakeholder groups (e.g., CNA, CFNU, CNSA) to keep on top of changing workforce trends. I think this is very important for the nursing profession in Canada.

Dr. Myrick: I want to thank you so much. You have provided such great insights into this particular issue and I think our readers will benefit greatly from it. d'infirmières dans divers pays ne pourra être réglée à moins de résoudre les causes sousjacentes à ce phénomène? Quelles sont les mesures que les professeures en sciences infirmières devraient prendre? Je comprends que vous dites que nous ne semblons pas avoir les mêmes problèmes que dans d'autres pays, mais je parle ici d'un point de vue global.

$D^{\text {re }}$ Hall : Il s'agit d'une question difficile, sans réponse facile. Personnellement, je suis d'avis que les causes principales de la pénurie, en plus d'un manque de planification des ressources humaines en santé, sont davantage liées à l'environnement et aux conditions de travail ainsi qu'à la migration des infirmières. Les infirmières partent (ou migrent) pour aller dans une autre province, un autre territoire ou un autre pays et ainsi évoluer et se développer dans un meilleur environnement de travail. Lors d'une recherche effectuée au moment d'une pénurie antérieure d'infirmières au Canada, et examinant l'émigration d'infirmières canadiennes aux États-Unis, j'ai constaté l'importance accordée à l'environnement et aux conditions de travail par les infirmières en recherche d'emploi. Contrairement à ce que plusieurs pensent, les principales motivations n'étaient pas le salaire, les avantages sociaux ou un climat ensoleillé. Elles ont plutôt consulté les sites Web des organisations à la recherche d'indices de l'importance qui était accordée aux infirmières : quelles opportunités de développement professionnel étaient décrites, quelle politique était énoncée et quel soutien était offert quant à la poursuite d'études aux cycles supérieurs. Elles m'ont rapidement dit que si elles ne voyaient pas beaucoup d'information sur les soins infirmiers sur le site, elles remettaient en question leur intérêt envers cette organisation, car elles interprétaient cela comme un signe que les infirmières n'étaient pas considérées comme des porfessionnelles.

Nous devons savoir ce que nos diplômées recherchent, particulièrement pour les prochaines générations. Cette semaine, j'ai entendu un bulletin de nouvelles où l'on discutait de la façon dont cette nouvelle génération veut être informée. Les jeunes ne veulent pas d'articles 
ou de longs rapports, ils préfèrent des points d'information. Ils veulent des informations rapides, précises et complètes; ils veulent pouvoir prendre une décision et aller de l'avant. S'ils veulent approfondir un sujet, ils iront chercher et trouver cette information eux-mêmes. Par extension, notre compréhension de ce que recherchent les futures infirmières change aussi. Nous devons en être conscientes particulièrement lors d'un manque d'infirmières. Cependant, dépendamment de l'endroit où vous vous trouvez ou de la personne à qui vous parlez, il est possible que la perception d'un manque d'effectifs soit différente. Le même phénomène a lieu aux États-Unis : certains chercheurs affirment qu'il y a une pénurie, d'autres non. Il s'agit de l'une de ces questions où l'on répond «ça dépend ». Le défi est de ne pas atteindre le point où une pénurie se manifeste. En effet, pourquoi faudrait-il se rendre là? Au plan des politiques de santé, est-ce que nous effectuons un suivi pour nous assurer que nous avons la maind'œuvre nécessaire pour les personnes dont nous prenons soin, que ce soit dans la communauté, à domicile ou dans les établissements de soins tertiaires? Sans Bureau de la politique des soins infirmiers et sans directrice nationale des soins infirmiers au pays, il est difficile de répondre à cette question. Nous avons perdu cette instance au niveau fédéral et, dans certains cas, nous voyons à peu près la même chose se produire dans certaines provinces et territoires. C'est pourquoi il y a un besoin réel pour l'ACESI de continuer de travailler avec d'autres groupes $d$ 'acteurs fédéraux en sciences infirmières ( $p$. ex., AIIC, FCSI, AEIC) pour rester à l'affût des tendances de la main-d'œuvre infirmière. Je crois que cela est très important pour la profession infirmière au Canada.

$D^{\text {re }}$ Myrick : Je vous remercie beaucoup. Vous avez fourni d'excellentes pistes de réflexion sur ce sujet et je crois que nos lectrices pourront en bénéficier grandement. 


\section{References}

Canadian Association of Schools of Nursing [CASN]. (2017). Registered Nurses Education in Canada Statistics, 2015-2016. Retrieved from https://www.casn.ca/2017/12/2015-2016-nursing-education-statisticsreport/

Canadian Institute for Health Information [CIHI]. (2018a). Regulated Nurses, 2017: Canada and Jurisdictional Highlights. Retrieved from https://secure.cihi.ca/estore/productSeries.htm?pc=PCC449

CIHI. (2018b). Regulated Nurses, 2017: Data Tables. Retrieved from https://www.cihi.ca/en/access-data-andreports

2015. McGillis Hall, L., Jones, C., Lalonde, M., Strudwick, B., \& McDonald, B. Not very welcoming: A survey of internationally educated nurses employed in Canada. GSTF Journal of Nursing and Healthcare, 2(2), 60-65. DOI 10.5176/2010-4804_2.2.78.

Canadian Council of Registered Nurse Regulators. (2017). NCLEX RN 2017: Canadian and International Results. Retreived from:

http://www.ccrnr.ca/assets/2018-nclex-rn-2017-canadian-and-international-results-ccrnr-en.pdf

\section{Références}

Association canadienne des écoles de sciences infirmières [ACESI] (2017). Statistiques sur la formation d'infirmières et d'infirmiers au Canada, 2015-2016. Extrait de : https://www.casn.ca/fr/2017/12/statistiquessur-la-formation-dinfirmieres-et-dinfirmiers-au-canada-2015-2016/.

Canadian Council of Registered Nurse Regulators (2017). NCLEX RN 2017: Canadian and International Results. Extrait de : http://www.ccrnr.ca/assets/2018-nclex-rn-2017-canadian-and-international-results-ccrnren.pdf.

Institut canadien d'information sur la santé [ICIS] (2018a). Infirmières réglementées 2017 : Canada and Jurisdictional Highlights. Extrait de : https://secure.cihi.ca/estore/productSeries.htm?pc=PCC449.

ICIS (2018b). Le personnel infirmier réglementé 2017 : tableaux de données. Extrait de : https://www.cihi.ca/fr/le-personnel-infirmier-reglemente-2017-tableaux-de-donnees.

Council of Ontario Universities (le 9 mai 2017). University Consortium Expands Courses and Opens Doors for Internationally Trained Nurses in Ontario. Extrait de : http://cou.on.ca/blog/university-consortium-expandscourses-opens-doors-internationally-trained-nurses-ontario/.

McGillis Hall, L., Jones, C., Lalonde, M., Strudwick, B. et McDonald, B. (2015). Not very welcoming: A survey of internationally educated nurses employed in Canada. GSTF Journal of Nursing and Healthcare, 2(2), pp. 60-65. https://doi.org/10.5176/2010-4804_2.2.78. 